\title{
Early Results on Depth of the Nascent Kenyan Derivative Market
}

\author{
Faith Mwende Christopher ${ }^{1}$, Amos Njuguna $^{1} \&$ Peter Kiriri $^{1}$ \\ ${ }^{1}$ Chandaria School of Business, United States International University- Africa, Nairobi, Kenya \\ Correspondence: Faith Mwende Christopher, Chandaria School of Business, United States International University- \\ Africa, Nairobi, Kenya. E-mail: faithlinge@gmail.com
}

Received: July 18, 2020

doi:10.5430/ijfr.v12n3p345
Accepted: September 6, 2020

Online Published: February 10, 2021

URL: https://doi.org/10.5430/ijfr.v12n3p345

\begin{abstract}
Despite their importance in hedging against risk and reducing price uncertainty, derivative markets remain undeveloped or absent in many African countries. This paper describes market depth using key trends observed in the Kenyan derivatives market for the first 30 weeks of trading using mixed methods. Market depth was measured by the number of open interests of 142 trading days ( 30 weeks. The market was described using trend analysis, tests of means, and thematic analysis. The results revealed a market highly dominated by one company's single stock futures (Safaricom Plc), whose overall trade was $68 \%$ of the 6179 open contracts. Further, the market has strong weekly swings fluctuating from no trade to a high of 326 and a weekly average of 206 contracts. The market segment of single stock futures is significantly deeper than that of equity index futures. The qualitative study attributed the results to limited knowledge on derivatives amongst investors, unclear market policies, few derivatives products, and skepticism associated with developing financial markets. The Nairobi Securities Exchange (NSE) is advised to intensify investor education, introduce market makers, add new derivatives products, and transform the Nairobi Securities Exchange Clearing House into a full Central Counterparty (CCP) structure to accelerate market depth. This will create a pathway to market depth through efficiency and reduction of operational risks.
\end{abstract}

Keywords: derivatives market, open interest, market depth, nascence

\section{Introduction}

A derivative is an agreement of worth whose value depends on a product's price in the cash market (Gupta 2017). These markets have substantially gained value and importance to become a strong pillar of the global financial system that enhances increased access to finance and financial deepening (LiPuma \& Lee, 2004). Developed countries have benefited immensely from derivative markets through various inventions and innovations in the industry. Among the benefits include self-insurance against the volatility of capital flows (Adelegan, 2009). For instance, in recent years, the derivatives market in South Africa has increased rapidly to support capital inflows and to support pricing, to unbundle and transfer risk market participants. According to Chidaushe (2018), foreign investors have increased two folds in JSE since the country's derivatives market. At the micro-level, the South African market enabled farmers to discover prices of maize and efficient management of price risk (Mezui, Rutten, Sekioua, Diaye, Kabanyane, Arvanitis, 2013).

Zimbabwe was successful at the early stages of derivatives trading. Unfortunately, the unprecedented price increase of the trading commodities and the unsuccessful government intervention led to the collapse of the futures market (Chidaushe, 2018). Additionally, the lack of price volatility and the declining volatility of Zambia and Zimbabwe's underlying spot market did not help in accelerating the market from its nascent stage (Chidaushe, 2018). Uganda was more successful but could not generate sufficient trade volumes in its nascent stage (Rashid et al., 2010).

The Kenyan derivative market operates within the Capital Markets Act, and the Capital Markets (Derivatives Markets) Regulations, 2015 and is operationalized through the Central Counter Party (CCP) Handbook. Emerging markets lag behind due to a number of challenges such as the high resources and cost required to introduce derivatives exchange as well as poor economic growth in some of the emerging markets (Aysun \& Guldi, 2011). Tsetsekos and Varangis (1997) established that emerging markets takes a relatively lengthy time to introduce derivative products due to relatively more developed stocks market compared to other financial sectors such as foreign exchange.

Several studies have been conducted to examine the derivatives market depth and to categorize successful and 
unsuccessful markets. Jobst (2008) discusses the prudent development of derivative markets citing the infrastructure, liquidity and sound regulations as the pillars of derivatives trading as well as enablers of depth. Similarly, Black (1986) established that the liquidity and price variability of the underlying cash market positively influences the success of derivatives market in New York Stock Exchange. Black(1986), statistically compared the failed and successful contracts and identified the probability of the contract to succeed is determined by volume size, volatility and liquidity. Further, Kim and Waweru (2015) studied Asian markets and established that liquidity of the underlying spot market, volatility of the underlying cash market and products traded determined the success of the derivatives market. These studies failed to agree on the accelerators of the market depth of derivatives in its nascent stage. Additionally, the studies were conducted in other countries hence presenting geographical and contextual gaps since Kenya operates in a different economic environment. This study thus sought to examine the Kenyan derivative market's market depth and provide recommendations to enhance increased trading.

\section{Literature Review}

As advanced by Kyle (1985), market depth theory expounds on the concept of derivatives market depth. The market depth position is closely related to the influence of liquidity, as both effects are positive due to the rise in trade. More exposure to the market is extremely useful because the more profoundly the market is, the more transactions the security price requires to be influenced (Danthine, 1978).

Black (1986) previously studied the relationship involving market depth and notes that the futures market is dubbed liquid because traders and investors can quickly buy or sell futures contracts without price effects. The analyst observed that the trades of individual hedgers in the thin markets might have substantial pricing consequences and large transaction costs. Chatrath and Song (2005) indicated that such trading costs are the rates traders are obliged to pay or compensate for future positions. While hedgers may take positions offsetting one another, a futures market will usually build more market liquidity in the way of attracting additional buyers if it is to be successful (Chatrath \& Song, 2005). Berkman and Eleswarapu (1998) criticized the theory arguing that it assumes asymmetric information available to all market players and that rational traders' expectations are homogenous. This is not the case in the market since several factors affect the stocks, such as the presence of market imperfections, corporate activities, among others. Berkman and Eleswarapu (1998) further argued that asymmetry produces a power gap in transactions, which often leads to a certain business loss

The derivatives market depth shows the number of open contract buying and selling orders at different prices (Kempf \& Korn, 1999). The higher the number of orders purchased and sold at each date, the greater the market depth. Various studies have affirmed that derivative markets with accelerated and deeper market depth have contracts with high trading volumes. In contrast, the shallow derivative market has a few numbers of contracts that have low trading volumes (Kim \& Waweru, 2013). According to Black (1986), the size of the underlying cash market is a determinant of contract complexity and thus a driver of the derivatives market scope, adding that it is a prescription for expanded derivatives market breadth where the cash market is high. Market size changes have a positive effect on the trading 7 volume of futures (Corkish, Holland and Vila, 1997).

Tashjian and Weissman (1995) study the effect of price volatility on market depth used volume traded as the proxy measure for the derivatives market depth while Sandor (1983) used a cut-off 1,000 contracts traded annually differentiate accelerated depth in derivatives contracts. Black (1986), using Wall Street Journal criterion, imposed that contracts should record at least 1,000 daily average volumes for the first three years to be considered to have an accelerated market depth. The present study thus used the number of open interests as proxy measures for derivatives of market value, both in single stock futures and equity index futures. Hypothetically, the market would be characterized as deep if it has greater volumes traded with an increasing trend showing a deepening market.

\section{Methodology}

Mixed methods design was applied in the present study guided by Cresswell, Hanson, Plano \& Morales (2007). Mixed methods blend qualitative and quantitative aspects in a single study to better understand the research problem (Curtis, 2011). Quantitative data consisted of transactions of daily single stock and index futures transactions starting from July $4^{\text {th }}, 2019$, to January $31^{\text {st }} 2020$ (142 trading days or 30 Weeks). Qualitative data was collected using personal interviews with 18 key informants who were purposively selected. These informants included: staff working at derivatives market at the NSE (NEXT), Capital Markets Authority (CMA), clearing members, consultants in derivatives, and knowledgeable trading members.

An ethical review was conducted, and a research permit issued by the National Commission of Science, Technology, and Innovation (NACOSTI), the Kenya government regulatory agency for research. Appropriate ethical principles, 
including informed consent, confidentiality, right to give information without coercion or duress, and the respondents' right to withdraw from the interview at their discretion, were applied.

Quantitative data were analyzed using descriptive statistics, frequency distributions, and trend analysis to describe trading patterns. Additionally, the study used an independent t-test to test the mean differences between the first 15 weeks and the second 15 weeks. The statistics were generated using SPSS version 20 and Stata version 16, and results presented using figures and tabular format. Qualitative information was analyzed thematically to validate or support quantitative information. The generated themes were used to explain and complement quantitative findings.

\section{Data Analysis and Findings}

\subsection{Instruments Traded in Kenya's Derivative Market}

\subsubsection{Single Stock Futures}

To be included in the single stock futures, the security underlying the futures contract must be listed on the NSE, included in the NSE 25 share index, have a minimum average turnover of KES 7 million over the last six months before the review, and have a market capitalization of at least KES 50 billion. Table 1 gives the details of the single stock futures that were listed at the NSE during the first day of trading.

Table 1. Derivatives product of the five companies

\begin{tabular}{|c|c|c|c|c|c|c|}
\hline $\begin{array}{l}\text { Company } \\
\text { (Equity) }\end{array}$ & Sector & & $\begin{array}{l}\text { Price per share } \\
\text { (KES) as of July } \\
42019\end{array}$ & $\begin{array}{l}\text { Turnover } \\
\text { (KES) }\end{array}$ & $\begin{array}{l}\text { Market } \\
\text { Capitalization } \\
\text { (KES) }\end{array}$ & $\begin{array}{l}\text { Size of } \\
\text { Derivative } \\
\text { Contract size }\end{array}$ \\
\hline $\begin{array}{l}\text { Safaricom } \\
\text { (SCOM) }\end{array}$ & Telecommunication & & 28.9 & $331.81 \mathrm{M}$ & $1.24 \mathrm{~T}$ & $\begin{array}{l}1000 \text { Safaricom } \\
\text { shares }\end{array}$ \\
\hline $\begin{array}{l}\text { KCB Bank Group } \\
(\mathrm{KCBG})\end{array}$ & Banking & & 38.18 & $130.49 \mathrm{M}$ & $165.35 \mathrm{~B}$ & $\begin{array}{l}1000 \text { KCBG } \\
\text { Bank shares }\end{array}$ \\
\hline $\begin{array}{l}\text { Equity } \\
\text { (EQYT) }\end{array}$ & Banking & & 40.5 & $347.80 \mathrm{M}$ & $191.51 \mathrm{~B}$ & $\begin{array}{l}1000 \quad \text { Equity } \\
\text { Bank shares }\end{array}$ \\
\hline $\begin{array}{lr}\text { East } & \text { African } \\
\text { Breweries } & \text { Ltd } \\
\text { (EABL) } & \end{array}$ & $\begin{array}{l}\text { Manufacturing } \\
\text { Allied }\end{array}$ & $\&$ & 199.74 & $7.89 \mathrm{M}$ & $169.62 B$ & $\begin{array}{l}100 \\
\text { Share }\end{array}$ \\
\hline $\begin{array}{l}\text { British American } \\
\text { Tobacco (BATK) }\end{array}$ & $\begin{array}{l}\text { Manufacturing } \\
\text { Allied }\end{array}$ & $\&$ & 510.92 & $148.5 \mathrm{M}$ & $49.50 \mathrm{~B}$ & $\begin{array}{l}100 \\
\text { Shares. }\end{array}$ \\
\hline
\end{tabular}

Source: Nairobi Security Exchange (2019).

As shown in Table 1, the contract price for the single stock futures depend on the current price of the underlying share at the point of enlisting in the market with the hurdle being KES. 100. Hence if the share price is less than KES. 100, the contract includes 1000 underlying shares, and if the price exceeds KES. 100, the contract includes 100 underlying shares. The single stock futures are cash-settled and are traded quarterly (March, June, September, and December).

\subsubsection{Equity Index Futures}

The contract price for the Equity Index Futures depends on the current price of the NSE-listed Equity Index. The Equity Index futures are cash-settled and are traded quarterly (March, June, September, and December). One index point is (KES 100), as shown in Table 2.

Table 2. Equity index futures

\begin{tabular}{llrlcc}
\hline Derivative & Segment & Product type & $\begin{array}{l}\text { Equity Index share Price } \\
\text { /(KES) as of July 4 2019 }\end{array}$ & $\begin{array}{c}\text { Size of 1 Derivative } \\
\text { Contract size (KES) }\end{array}$ \\
\hline $\begin{array}{l}\text { Equity Index } \\
\text { Futures }\end{array}$ & $\begin{array}{l}\text { Equity Index } \\
\text { listed on the NSE }\end{array}$ & $\begin{array}{l}\text { NSE25 Share } \\
\text { Index (N25I) }\end{array}$ & 3,603 & 100 \\
\hline Sourat & & & \\
\hline
\end{tabular}

Source: Nairobi Security Exchange (2019). 


\subsection{Market Depth of Single Stock Futures}

\subsubsection{Open Interests}

The market depth was measured by the number of open interests defined as the total number of contracts traded from July $4^{\text {th }} 2019$ to January $31^{\text {st }} 2020$ (a total of 142 trading days or 30 weeks). Table 3 shows open interests descriptive summary for single stock futures.

Table 3. Total open interests

\begin{tabular}{llccc}
\hline Stock & Number of weeks & Total Number of Contracts Traded & Percentage & Weekly average \\
\hline SCOM & 30 & 4189 & $67.79 \%$ & 140 \\
EQTY & 30 & 514 & $8.32 \%$ & 17 \\
KCBG & 30 & 1232 & $19.94 \%$ & 41 \\
EABL & 30 & 135 & $2.18 \%$ & 5 \\
BATK & 30 & 109 & $1.76 \%$ & 4 \\
Total & 30 & 6179 & $100 \%$ & 206 \\
\hline
\end{tabular}

Source: Data Processed

As shown in Table 3, the total contracts traded were 6179 contracts of which Safaricom single stock futures amounted to 68\% ( $\mathrm{n}=4189)$, KCBG group $19.94 \%(\mathrm{n}=1232)$, Equity $8.32 \%(\mathrm{n}=514)$, EABL $2.18 \%(\mathrm{n}=135)$ and BATK $1.76 \%(n=109)$. On average, SCOM single stock futures had 140 contracts weekly, KCBG 41, Equity 17, EABL 5 and BATK 4.

Key informants attributed Safaricom's dominance of the market activity to its high liquidity, rank as the most profitable company in East Africa, perceived stability, and market confidence amongst the investors. The low activity by BATK and EABL was attributed to its high prices and the fact that they require an initial margin of around KES 7000 while Safaricom's initial margin is around KES 1000. Additionally, unlike Safaricom Plc, BATK is not as prominent, and there is not much noise in the market regarding BATK hence low activity in both the spot market and derivatives. EQTY and KCBG stocks operate in the financial and banking industry, reminisced after the scrapping of the interest rate cap; hence they are quite stable, explaining their average performance.

\subsubsection{Maximum Contracts Traded}

There were weeks and days when there was a high level of activity in the market. Table 4 shows the maximum contracts traded in the single stock futures market for each of the five single stock futures. The maximum contracts traded in a single week were 326, 40, 100, 11, and 10 for Safaricom, Equity, KCBG, EABL, and BATK.

Table 4. Maximum contracts traded

\begin{tabular}{lcl}
\hline Company & $\begin{array}{c}\text { Maximum number of contracts } \\
\text { traded }\end{array}$ & Dates (weekly) \\
\hline SCOM & 326 & 9 th $-13^{\text {th }}$ September 2019. (Week 10) \\
EQTY & 40 & $25^{\text {th }}-29^{\text {th }}$ November 2019. (week 21) \\
KCBG & 100 & July $292019-$ August 2 2019 (week4) \\
& & $5^{\text {th }}-9^{\text {th }}$ August 2019 (week 5) \\
& $13^{\text {th }}-16^{\text {th }}$ August 2019 (week 6) \\
& $19^{\text {th }}-30^{\text {th }}$ August 2019 (week 7 and 8) \\
EABL & July 11 29 2019 - \\
& & August 2 2019 (week 3) \\
BATK & 10 & $18^{\text {th }}$, November - November 29 2019 (week 20 and 21) \\
\hline SOure
\end{tabular}

Source: Data Processed. 


\subsubsection{Minimum Contracts Traded}

There were weeks when the derivative instruments of four of the companies were not traded. Table 5 shows the minimum open interests and the number of days where there were no contracts traded. According to experts, the market activity increased when the contracts neared the expiry date. This was due to more accurate information in the market and that investors were looking to close and open new contracts. Therefore, months such as September and November saw many contracts traded as they were near the expiry dates of the September and December contracts.

Additionally, it was revealed that the banking stocks performed better after the scrapping of the interest rate cap on banks in November 2019, which had a domino effect on stock performance. However, what attributed KCBG to have more market activity during July and August 2019 was the release of the company's half-year financial results (as of June 30 2019), which acknowledged the improved company performance. Further, it was revealed that the inconsistency in market activity was caused by speculation and information loops whereby traders end up trading particular stock after speculation of some important positive information.

Table 5. Minimum number of contracts traded

\begin{tabular}{|c|c|c|c|c|}
\hline Company & $\begin{array}{l}\text { Minimum number of } \\
\text { contracts traded }\end{array}$ & Dates & $\begin{array}{c}\text { Number of Days } \\
\text { of Inactivity }\end{array}$ & $\begin{array}{c}\text { Percentage } \\
\text { of } \\
\text { Inactivity }\end{array}$ \\
\hline SCOM & & $\begin{array}{c}\text { December } 6312019 \text { to January } 3 \\
2020 \text { (week 26) }\end{array}$ & 0 & $0 \%$ \\
\hline EQTY & 0 & $\begin{array}{c}\text { From September } 23 \text { to November } 1 \\
2019 \text { (week } 12 \text { to week 16) and } \\
\text { December } 31,2019 \text {, to January } 3 \\
2020 \text { (week 26). }\end{array}$ & 26 Days & $18.4 \%$ \\
\hline KCBG & 0 & $\begin{array}{l}\text { September } 23 \text { to October } 112019 \\
\text { (week } 12 \text { to week 14) and } 31^{\text {st }} \\
\text { December } 2019 \text { to January } 32020 \\
\text { (week 26). }\end{array}$ & 17 Days & $12.1 \%$ \\
\hline EABL & 0 & $\begin{array}{c}\text { From } 7^{\text {th }} \text { to October } 112019 \text { (week } \\
\text { 14) and December } 31,2019 \text {, to } \\
\text { January } 32020 \text { (week 26) }\end{array}$ & 8 days & $5.7 \%$ \\
\hline BATK & 0 & $\begin{array}{l}\text { From August } 5 \text { to October } 252019 \\
\text { (week } 4 \text { to week 16). }\end{array}$ & 57 Days & $40.4 \%$ \\
\hline
\end{tabular}

Source: Data Processed.

The minimum contracts traded in a single week for Safaricom was 6 contracts traded during the week 26. The other four single stock futures no trade for $18.4 \%, 12.1 \%, 5.7 \%$, and $40.4 \%$ of the 141 days of derivative trading for Equity, KCBG, EABL, and BATK, respectively.

\subsubsection{Weekly Analysis of the Contracts Traded}

Table 6. Descriptive statistics for open interest (Single stock futures)

\begin{tabular}{lc}
\hline Variable & Y1 $(\mathbf{N}=\mathbf{3 0})$ \\
\hline Mean & 206 \\
Std. Dev. & 1.28 \\
Min & 9 \\
Max & 451 \\
Mode & 131,239 \\
Median & 210 \\
\hline Source: Data Processed.
\end{tabular}

Source: Data Processed. 
The five companies' open interests were summed to obtain the number of contracts traded weekly in the derivatives market. Table 6 shows that, on average, 206 contracts are traded weekly in single stock futures derivatives market with a standard deviation of 1.28 . The minimum number of contracts traded in a week was 9 (week $26-30^{\text {th }}$ December 2019 to January 3 2020). The maximum number of contracts traded was 451 traded on week 10 (September 9 to September 13 2019). The series was bi-modal with two modes of 131 and 239. The median of the 30 -week series was 210. Figure 1 shows the trend of the contracts traded.

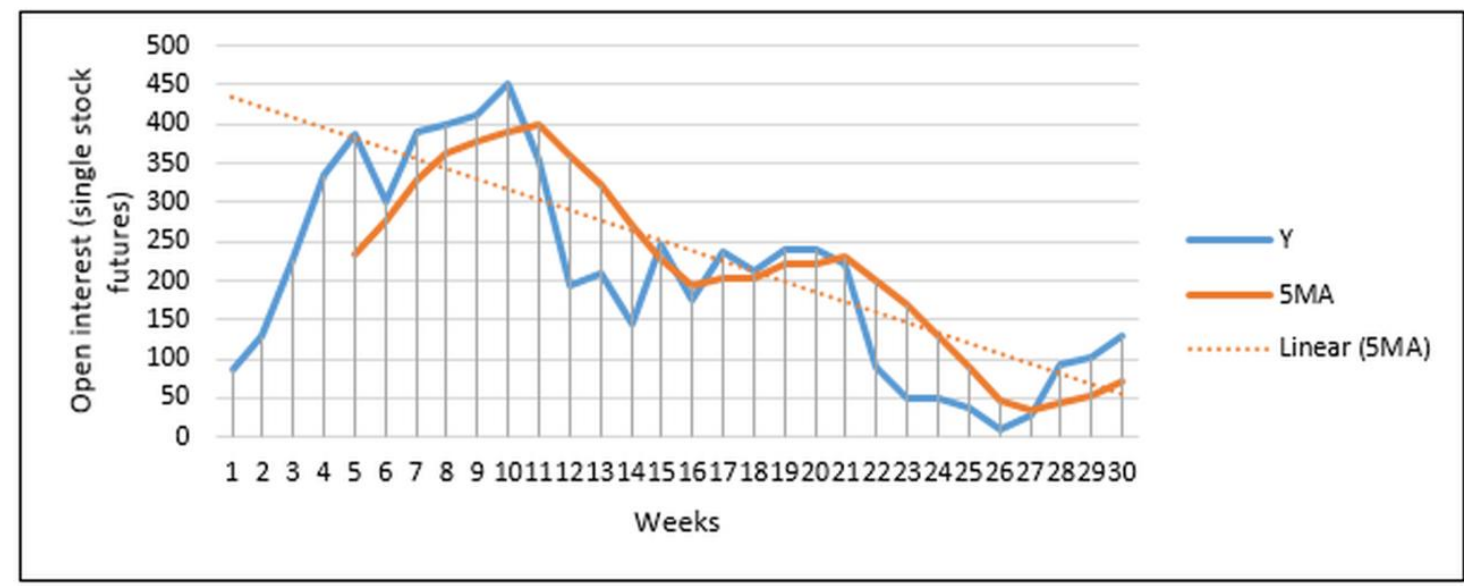

Figure 1. Open interest trend for single stock futures (Weekly Data for 30 weeks (July 4th, 2019, to January 31st 2020)

Source: Data Processed.

As shown in Figure 1, the number of single stock futures contracts traded over the 30 weeks has declined, which implies that the market activity is declining. The derivatives experts argued that this trend could be attributed to different factors such as the excitement of new products when the derivatives market started, followed by a slow start of the market. The key informants supported the notion that the market activity in equity index futures will improve in the long term if more institutional players get in the market. Institutional players like pension funds and big corporates are the ones who will choose equity index futures for hedging and getting exposure to the broad Kenya Market. Additionally, there will be more traders interested in the equity index futures after investor education in the long term.

Table 7 shows the independent t-test between the first 15 weeks and the second 15 weeks over the 30 weeks trading period. This test of mean differences was used to compliment the trend analysis by establishing whether the market depth of single stock futures has increased or decreased, given the two periods. The results were presented in Table 7.

Table 7. Test of mean differences

\begin{tabular}{lccccccc}
\hline & N= (30) & Mean & Std. Deviation & Mean difference & t & df & sig. \\
\hline First 15 weeks & 15 & 306 & 1.19 & 140 & 3.475 & 23 & 0.02 \\
Second 15 weeks & 15 & 166 & 8.07 & & & & \\
\hline
\end{tabular}

Source: Data Processed.

As shown in Table 7, the mean difference between the first 15 weeks and the last 15 weeks was 140 . The mean of the number of contracts traded during the first 15 weeks and the second 15 weeks was 306 and 166, respectively. The mean difference was significant $(\mathrm{p}=0.02<0.05)$. This revealed a significant mean difference between the first 15 weeks and the second 15 weeks of trading.

The qualitative information revealed that decreasing market depth was attributed to the fact that traders like to hold contracts for a long period to explore the market during the nascent stage. Therefore, there were no new contracts since the existing contracts have not been closed yet. Additionally, it was revealed that there are not many contracts 
in the market. Some experts felt that the criteria for selecting a stock to qualify to be in the derivatives market could be limiting, and that's why we have few contracts. Few stocks qualified to be used to design the derivatives contracts. Others felt that NSE should relax the entry criteria for a stock to qualify for the derivatives list to encourage more contracts in the derivatives market by having more companies joining the list.

Additionally, the experts attributed the declining trend to focus on a few futures products, unlike other markets such as South Africa or India, where they have other products like options and commodities. They argued that it limits the client if they want to trade in something else and not futures contracts. Additionally, it was noted that there was low liquidity in the derivatives market, explained by the fact that early excitement subsided due to a lack of experienced traders and clients in the market.

Table 8 shows the distribution of the data using skewness and kurtosis for equity index futures. The open interest was positively skewed (coefficient of skewness $=0.279$ ) and had a platykurtic distribution (coefficient of kurtosis $=$ 2.015).

Table 8. Skewness and Kurtosis

\begin{tabular}{lcc}
\hline Variable & Skewness & Kurtosis \\
\hline Open Interest & $\mathbf{0 . 2 7 9}$ & $\mathbf{2 . 0 1 5}$ \\
\hline
\end{tabular}

Source: Data Processed.

\subsection{Equity Index Futures Market Depth (Open Interest)}

The market depth for equity index futures was measured by the number of open interests defined as the total number of contracts traded from July $4^{\text {th }} 2019$ to January $30^{\text {th }} 2020$ (a total of 142 trading days or 30 weeks), and Table 9 shows the summary results.

Table 9. Descriptive statistics for open interests (Equity index futures)

\begin{tabular}{lc} 
Variable & Y2 \\
\hline Number of weeks & 30 \\
Total & 58 \\
Mean & 2 \\
Std. Dev. & 2.26 \\
Min & 0 \\
Max & 5 \\
Mode & 0 \\
Median & 0.5 \\
Weeks with no activity & 15 \\
Percentage of weeks of no activity & $50 \%$ \\
\hline
\end{tabular}

Table 9 shows that a total of 58 contracts were traded in equity index futures. On average, 2 equity index futures contracts were traded weekly with a standard deviation of 2.26 . The minimum number of contracts traded weekly was 0, which were traded from week 1 to week 4 (July 8, 2019, to August 2 2019) and week 10 to week 20 (September 9, 2019, to November 22 2019). The maximum number of contracts traded was 5 traded on week 7 and week 8 (August 19, 2019, to August 30 2019), week 24 (December 16, 2019, to December 20 2019) and week 27 to week 30 (January 6, 2020, to January 30 2020). The mode of the 30-week series was 0 , and the median was 0.5 . There were 15 weeks (50\% of the trading days) when there was no activity in equity index futures.

According to the derivatives experts, this is because of the cost issues citing that equity Index futures are expensive. Retail investors who are the current players seek cheaper options like Safaricom in single stock futures. Additionally, most investors are not familiar with equity index futures, and it's underlying on the spot market. Due to lack of familiarity with the Equity Index futures, investors would rather get exposure on the spot market since it's more vibrant than the derivatives market. Therefore, the majority of the derivatives specialists suggested that investor 
education and training would improve market activity. Figure 2 shows the trend analysis of open interest in equity index futures.

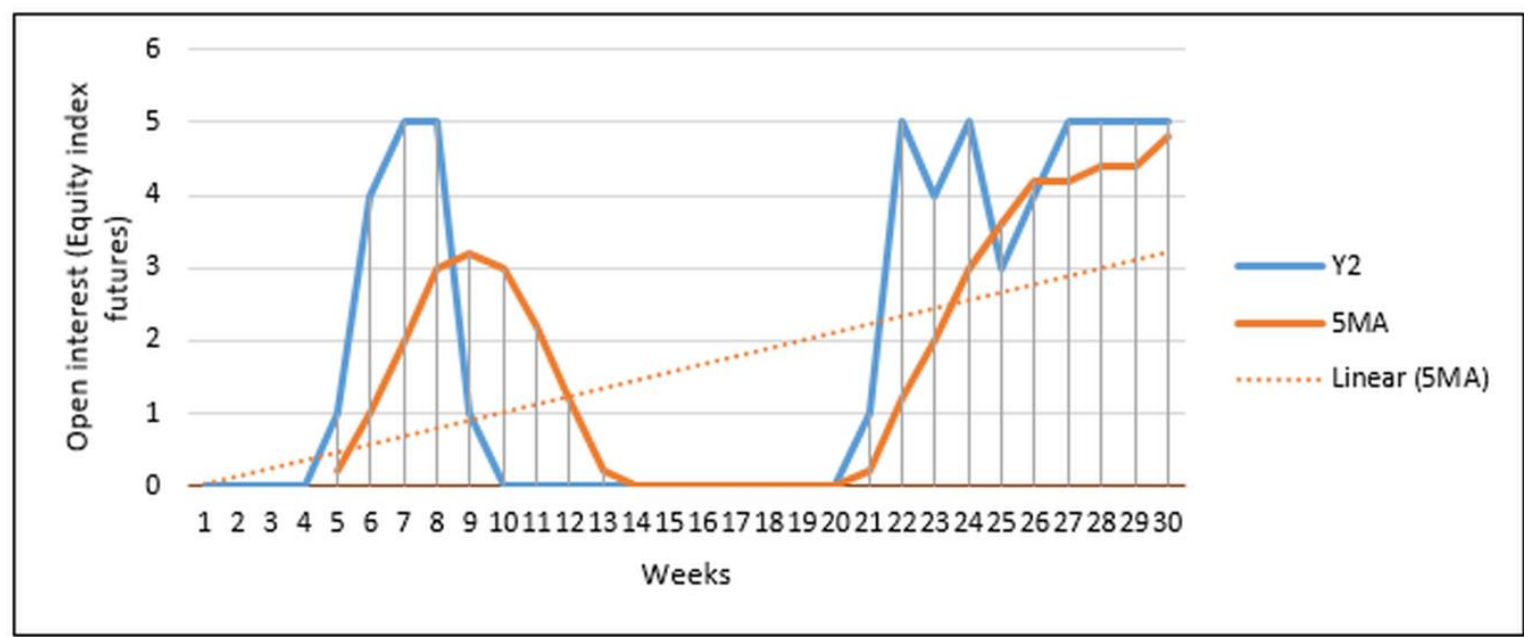

Figure 2. Open interest trend for equity index futures (Weekly Data for 25 weeks (July 4th, 2019, to January 31st 2020)

Source: Data Processed.

Figure 2 shows that the number of equity index futures contracts traded over the 30 weeks has been increasing. However, the trend decreased from week 12 to week 15 and hit the lowest from week 16 to 20, after which the contracts traded started increasing. The derivatives experts argued that this trend could be attributed to different factors such as the excitement of new products when the derivatives market started, followed by a slow start of the market. In contrast, the increase in the number of contracts traded in November 2019 could be attributed to scraping the interest rate capping on banks in November 2019.

Table 10 reveals the independent t-test between the first 15 weeks and the second 15 weeks over the 30 weeks trading period. This mean difference test was used to test whether there was a significant difference between the two periods, and the results were presented in Table 10.

Table 10. Test of mean differences

\begin{tabular}{lccccccc} 
& N=(30) & Mean & Std. Deviation & Mean difference & t & df & sig. \\
\hline First 15 Weeks & 15 & 1.333 & 2.059 & -0.05128 & -0.062 & 23 & 0.95 \\
Second 15 Weeks & 15 & 1.38 & 2.063 & & & & \\
\hline
\end{tabular}

Source: Data Processed.

As shown in Table 10, the mean difference between the first and last 15 weeks was -0.05128 . The mean of the first 15 weeks and the second 15 weeks was 1.333 and 1.38 , respectively. The mean difference was insignificant, as revealed by the p-value of 0.95 , which was greater than the critical value of 0.05 . This shows that there was no significant variation of equity index futures between the two quarters.

Table 11 shows the data distribution using skewness and kurtosis for the open interest in equity index futures. According to the skewness results, open interest in equity index futures was positively skewed (skewness $=0.45$ ) with a platykurtic distribution (coefficient of kurtosis $=1.338$ ). 
Table 11. Skewness and Kurtosis

\begin{tabular}{lcc}
\hline Variable & Skewness & Kurtosis \\
\hline Open Interest & $\mathbf{0 . 4 5}$ & $\mathbf{1 . 3 3 8}$ \\
\hline
\end{tabular}

Source: Data Processed.

\subsection{Emerging Issue From the Study}

The experts established that the Clearing House of the Nairobi Securities Exchange that runs the derivatives market is yet to attain a full Central Counterparty (CCP) structure. The experts pointed out that the derivatives market's clearinghouse should consider having discussions with the Central Bank of Kenya (CBK) to obtain direct clearing rights instead of utilizing the services of commercial banks. The NSE Clearing House has achieved CCP lite level, which is one step short of full CCP because it still used commercial banks (currently Co-operative Bank and Stanbic Bank) to perform clearing services on its behalf. To achieve Full CCP status, the NSE must centralize risk by doing away with the clearing members (banks). The study further noted that 'Centralizing Risk' have the following advantages: It will totally remove the risks of pooling together derivative market funds with the normal corporate banking exposures and hence will increases efficiency, reduces turnaround time given only one entity (the clearinghouse) will be performing the derivatives clearing functions; It reduces the operational risks of having many commercial banks clearing on the NSE's behalf who have different internal policies, knowledge, systems, and culture; It will be cheaper for the client and ecosystem given there will be fewer intermediaries involved (no banks); it will eliminate insolvency issues that a collapsed bank which operates clearing functions for the derivative markets can cause, and finally it will increase the number of brokers and marketing spread assuming the commercial banks will now apply to be derivative brokers.

\section{Discussion, Conclusion, and Recommendation}

\subsection{Discussion}

According to Rashid et al. (2010), though the critical minimum size is not defined, most African countries' market size appears to be small compared with the countries that have active derivatives markets. The author adds that underdeveloped financial markets may also make it difficult for hedgers and speculators to actively participate in the derivatives market. The study described the derivatives market in Kenya at its nascent stage. Other studies such as those of Black (1986), Kim and Waweru (2015), and Tashjian and Weissman (1995) used the volume of contracts traded as the measure of market depth. This is attributed to the fact that those studies focused on a relatively developed derivative market compared to the current study, which focused on the Kenyan young derivatives market.

From the results, the instruments traded are single stock futures (whose underlying assets are stocks of companies that meet certain stated criteria) and Equity index futures (whose underlying asset is the NSE 25 share index). The single stock futures listed in the NEXT included stocks of five companies, namely, Safaricom Plc (SCOM), Equity Bank Group, Kenya Commercial Bank Group (KCBG), East African Breweries Limited (EABL), and British American Tobacco Kenya (BATK). The results imply that Kenya's derivatives market is still in its nascent stage, which agrees with the Black (1986) results that derivatives contracts are successful after completing more than 1000 contracts in their third year.

Concerning Equity Index Futures, the study established low liquidity in the equity index side due to complexity and lack of familiarity. This was in line with Kim and Waweru (2015), who asserted that lack of liquidity negatively affects the derivatives' depth.

\subsection{Conclusion}

Safaricom stocks highly dominate the single stock futures market. Safaricom stocks also have the lowest percentage of days of inactivity as compared to their peers in single stock futures. BATK has the highest percentage of days of inactivity in single stock futures, which is attributed to a lack of unfamiliarity with the stock and expensive shares. Overall, the market activity of single stock futures has been on a decline. On that basis, the study concludes that despite the high market activity in Safaricom, KCBG, and EQTY stock futures, the decline of market activity in single stock futures shows that the market is still in its nascent stages. Market activity in single stock futures is low compared to single stock futures. However, the trend of contracts traded in equity index futures increases as investors familiarize themselves with the market.

The study sums up that the lack of liquidity in derivatives counters is hurting the derivatives market depth from the qualitative information. In that regard, the study concludes that among the factors that have hindered the derivatives 
market depth are the unfamiliarity of the market, unclear policies, lack of liquidity in derivatives counters, and poor investor knowledge. The study concludes that these issues limit the derivatives; hence awareness of the derivatives market, the introduction of new products, and the market maker is critical if the market is to evolve from the nascent stage. From the emerging issue, the study establishes a need for a robust Central Counterparty Clearing House (CCP) that meets global standards to help manage the risk.

\subsection{Recommendations}

This study recommends the Capital Market Authority (CMA) of Kenya and Nairobi Security Exchange (NSE) to increase the investor education to increase the derivatives market awareness to improve derivative market activity. Additionally, NEXT should aim to introduce new products such as commodity futures and currency futures, which will see the market depth of the derivatives market in Kenya broaden. Further, the introduction of market makers will improve derivatives counters' liquidity, hence increasing activity in the derivatives market.

The NSE is encouraged to create a robust Central Counterparty Clearing House (CCP) which meets global standards. The Clearing House of the derivatives market should consider applying to the central bank of Kenya for direct membership to the National Payment System to obtain direct clearing rights instead of utilizing commercial banks (Co-operative Bank and Stanbic Bank). This would increase efficiency, reduce costs and operational risk, and increase the ability to innovate.

\section{Limitations of the Study and Suggestions for Further Research}

The study's limiting concern was the few months' data, which potentially inhibited extensive examination of the derivatives market depth. Therefore, future studies should be done for longer periods to assess the derivatives market depth and its evolution from nascency. Additionally, the study employed open interest as the proxy measure of derivatives market depth. Other studies from the literature review employed trading volume as the proxy measure of the derivatives market depth. Future studies should use volume traded as a measure of derivatives market depth. Generally, qualitative results cannot be verified, do not show causality, is subjective, and may not be statistically representative. These limitations could have permeated the qualitative part of the study.

\section{References}

Adelagan, O. J. (2009). The derivatives market in South Africa: Lessons for sub-Saharan African countries. Working Paper No. 09/196. International Monetary Fund. Retrieved from https://www.imf.org/en/Publications/WP/Issues/2016/12/31/The-Derivatives-Market-in-South-Africa-Lessons-f or-Sub-Saharan-African-Countries-23250

Aysun, U., \& Guldi, M. (2011). Derivatives market activity in emerging markets and exchange rate exposure. Emerging Markets Finance and Trade, 47(6), 46-67.

Berkman, H., \& Eleswarapu, V. R. (1998). Short-term traders and liquidity: A test using Bombay Stock Exchange data. Journal of financial Economics, 47(3), 339-355.

Black, D. G. (1986). Success and failure of futures contracts: Theory and empirical evidence. New York, NY: Salomon Brothers.

Chatrath, A., \& Song, F. (2005). Futures commitments and commodity price jumps. The Financial Review, 34(3), 95-111.

Chidaushe, W. K. (2018). The impedements and best practice use of derivatives in Zimbabwe, Botswana and South Africa. Journal of Business \& Financial Affairs, 7(2), 32-45.

Corkish, J., Holland, A., \& Vila, A. (1997). The determinants of successful financial innovation: An empirical analysis of futures innovation on LIFFE. Working Paper No. 70. Bank of England. https://www.bankofengland.co.uk/working-paper/1997/the-determinants-of-successful-financial-innovation.

Gupta, S. L. (2017). Financial derivatives: Theory, concepts and problems (2nd ed.). Delhi: PHI Learning Private Limited.

Jobst, A. A. (2008). The development of equity derivative markets: An examination of current standards and challenges in emerging Asia. International Journal of Emerging Markets, 3(2), 163-180.

Kempf, A., \& Korn, O. (1999). Market depth and order size. Journal of Financial Markets, 2(1), 29-48

Kim, Y. K., \& Waweru, F. (2015). Factors Behind Exchange-Traded Derivatives Products Success. Retrieved from https://su-plus.strathmore.edu/handle/11071/3633 
Kyle, A. S. (1985). Continuous auctions and insider trading. Ecometrica, 53(46), 1315-1335.

LiPuma, E., \& Lee, B. (2004). Financial derivatives and globalization of risk. Durham, NC: Duke University Press.

Mezui, M., Rutten, L., Sekioua, S., Diaye, M. M., Kabanyane, N., Arvanitis, Y., \& Nekati, B. (2013). Guidebook on African Commodity and Derivatives Exchanges. Working Paper No. 42998. African Development Bank. Retrieved

from https://www.afdb.org/en/documents/document/guidebook-on-african-commodity-and-derivatives-exchanges-42 998

Rashid, S., Winter-Nelson, A., \& Garcia, P. (2010). Purpose and potential for commodity exchanges in African economies. Working Paper No 1035. International Food Policy Research Institute. Retrieved from https://www.ifpri.org/publication/purpose-and-potential-commodity-exchanges-african-economies

Tashjian, E., \& Wiessman, M. (1995). Advantages to Competing with Yourself: Why an Exchange Might Design Futures Contracts with Correlated Payoffs. Journal of Financial Intermediation, 4(2), 378-391.

Tsetsekos, G., \& Varangis, P. (2013). The Structure of Derivatives Exchanges: Lessons from Developed and Emerging Markets. Working Paper No 1887. World Bank Organization. Retrieved from https://elibrary.worldbank.org/doi/abs/10.1596/1813-9450-1887

\section{Copyrights}

Copyright for this article is retained by the author(s), with first publication rights granted to the journal.

This is an open-access article distributed under the terms and conditions of the Creative Commons Attribution license (http://creativecommons.org/licenses/by/4.0/). 